The Journal of Vitaminology 12, 179-185 (1966)

\title{
NADH-DIAPHORASE ACTIVITY IN SUBCELLULAR FRACTIONS OF MOUSE TISSUES
}

\author{
KAZUMA MIYAJI ${ }^{1}$ AND YOSHIHISA MORIZONO ${ }^{2}$ \\ Department of Internal Medicine, School of Medicine, \\ Kyushu University, Fukuoka
}

(Received February 10, 1966)

NADH-diaphorase and succinic dehydrogenase are important flavoenzymes involved in the electron-transfer system, but they differ at least in two points regarding the activities in tissues.

First, succinic dehydrogenase is localyzed in mitochondria (1), whereas NADHdiaphorase is detectable not only in mitochondria but also much in microsomes (2) and a little in nuclei (3), showing a wide distribution. The NADH-diaphorase is involved in cell respiration, but the physiological functions of that occuring in microsomes and nuclei is obscure and the electron acceptors for it remain unclarified.

Second, riboflavin deficiency causes marked lowering of succinic dehydrogenase activity (4), whereas NADH-diaphorase is known to be strongly resistant to such deficient states (5) even in a tissue like mucous membranes of the small intestine where epitheliar cells are actively proliferated by mitosis on the one side and desquamated on the other (6).

This finding (6) led the authors to the experiment which showed that the $\mathrm{NADH}$-diaphorase activity was enhanced just before the cell division in the Ehrlich ascites tumor (7), suggesting a participation of the enzyme in cell division (8). The NADH-diaphorase activity was found concentrated in microsomes in the Ehrlich ascites tumor cells and most of the enzyme activities, if not all of them, are assumed to be involved in cell division (8). Thus the significance of the $\mathrm{NADH}$-diaphorase activity in microsomes, hitherto remained obscure, has become clear to some extent.

For further confirmation, the experiment were carried out on the distribution of the NADH-diaphorase activity in subcellular fractions of various tissues.

\section{EXPERIMENTAL}

\section{Animals and Tissues}

Normal male $\mathrm{CF}_{1}$ mice, weighing about $20 \mathrm{~g}$, were fed Oriental solid diets. After decapitation, the liver, heart, kidney, femoral muscle and mucous membrane of the small intestine were removed immediately. The mucous membrane was prepared as previously described (6) so as to containe mainly the epitheliar cells.

\footnotetext{
${ }^{1}$ Present address: Department of Internal Medicine, Shiohama Hospital, School of Medicine, Mie Prefectural Universitry, Tsu

2 宮地一馬, 森園義久。
} 


\section{Fractionation of Tissues}

The tissue, $100 \mathrm{mg}$, was homogenized in $10 \mathrm{ml}$ of $0.25 \mathrm{M}$ sucrose solution by a glass homogenizer. The homogenate was fractionated by centrifugation using a Hitachi Ultracentrifuge, Type $40 \mathrm{P}$, according to the method of Strittmatter et al. (9) to obtain nuclear, mitochondrial, and microsomal fractions, and supernatant. The all procedures were carried out at $0-5^{\circ}$. The nuclei, mitochondria, and microsomes thus prepared were suspended separately in $2 \mathrm{ml}$ each of $0.05 \mathrm{M}$ phosphate buffer, $\mathrm{pH}$ 7.4.

\section{Assay of NADH-Diaphorase Activity}

The activity was assayed by the method of Burch et al. (5). The reaction mixture contained, in a total volume of $3 \mathrm{ml}, 0.1 \mathrm{ml}$ of $7.5 \mathrm{mM} \mathrm{K}{ }_{3} \mathrm{Fe}(\mathrm{CN})_{6}, 0.1 \mathrm{ml}$ of $750 \mathrm{~m} M$ nicotinamide, $0.1 \mathrm{ml}$ of $3.0 \mathrm{~m} M \mathrm{NADH}, 0.1 \mathrm{ml}$ of $30 \mathrm{mM} \mathrm{KCN}, 2.5 \mathrm{ml}$ of $50 \mathrm{mM}$ phosphate buffer $(\mathrm{pH} 7.4)$ and $0.1 \mathrm{ml}$ of the sample. The decrease of the absorbance at $350 \mathrm{~m} \mu$ was followed by determining the optical density at $350 \mathrm{~m} \mu$ in a Beckman DU Spectrophotometer at $20 \pm 3^{\circ}$. The activity was expressed as the decrease of the absorbance per minute per the original volume of $2 \mathrm{ml}$.

The proteins in the sample were determined by the method of Lowry et al. (10) using Folin's phenol reagent and the specific enzyme activity was calculated.

\section{Assay of Succnic Dehydrogenase Activity}

Succinic dehydrogenase activity was measured to estimate the percentage contamination of mitochondria in each fraction. The reaction system was composed of, according to Seligman (11), $0.1 \mathrm{ml}$ of $0.2 \mathrm{M}$ sodium succinate, $0.2 \mathrm{ml}$ of $0.2 \%$ neotetrazolium chloride, and $0.2 \mathrm{ml}$ of the sample in a total volume of $0.6 \mathrm{ml}$. After incubation of the mixture for 30 minutes at $37^{\circ}, 0.5 \mathrm{ml}$ of $10 \%$ formalin was added to stop the reaction, followed by extraction of formozan thus formed with a mixture of ether-acetone $(1: 1, \mathrm{v} / \mathrm{v})$ and the absorbance at $520 \mathrm{~m} \mu$ was measured. The activity was expressed as the absorbance in $10 \mathrm{ml}$ of the extract.

\section{RESULTS}

\section{Distribution of NADH-Diaphorase Activity in Subcellular Fractions}

Distribution of NADH-diaphorase activity in the liver, kidney, heart, femoral muscle and mucous membrane of the small intestine was determined and the results shown in Table 1 were obtained. The activity was found to exist mainly in the mitochondrial and microsomal fractions and little in the supernatant and nuclear fraction. The tissues tested except for the mucous membrane of the small intestine contained the NADH-diaphorase activity mostly in the mitochondrial fraction or almost equally in both mitochondrial and microsomal fractions. The small intestinal mucosa contained, however, markedly higher concentration of the enzyme in the microsomal fraction than in the mitochondria.

\section{Distribution of Succinic Dehydrogenase Activity in Subcellular Fractions}

In order to know the extent of mitochondrial contamination in the subcellular fractions used in the experiment succinic dehydrogenase activity was measured. As listed in Table 2, the supernatants from various tissues tested showed scarcely any activity of succinic dehydrogenase. It was also poor in the nuclear fraction. 
TABLE 1

NADH-Diaphorase Activity Uncorrected in Subcellular Fractions of Mouse Tissues

A, activity; B, percentage activity.

\begin{tabular}{|c|c|c|c|c|c|c|c|}
\hline Organ & $\begin{array}{l}\text { No. } \\
\text { cas }\end{array}$ & of & $\begin{array}{l}\text { Super- } \\
\text { natant }\end{array}$ & $\begin{array}{l}\text { Micro- } \\
\text { somes }\end{array}$ & $\begin{array}{l}\text { Mitochon- } \\
\text { dria }\end{array}$ & Nuclei & Total \\
\hline Liver & 10 & $\begin{array}{l}\mathrm{A} \\
\mathrm{B}\end{array}$ & $\begin{array}{r}0.0677 \\
\pm 0.0596 \\
17.09\end{array}$ & $\begin{array}{c}0.1384 \\
+0.0955 \\
34.94\end{array}$ & $\begin{aligned} & 0.1464 \\
\pm & 0.0629 \\
& 36.96\end{aligned}$ & $\begin{array}{r}0.0436 \\
\pm 0.0202 \\
11.01\end{array}$ & $\begin{array}{r}0.3961 \\
\pm 0.1547\end{array}$ \\
\hline Kidney & 10 & $\begin{array}{l}\mathrm{A} \\
\mathrm{B}\end{array}$ & $\begin{aligned} & 0.0409 \\
&+ 0.0351 \\
& 14.40\end{aligned}$ & $\begin{array}{c}0.0866 \\
\pm 0.0374 \\
30.49\end{array}$ & $\begin{aligned} & 0.1134 \\
& \pm 0.0383 \\
& 39.93\end{aligned}$ & $\begin{array}{r}0.0431 \\
\pm 0.0184 \\
15.18\end{array}$ & $\begin{array}{r}0.2840 \\
\pm 0.0834\end{array}$ \\
\hline $\begin{array}{l}\text { Heart } \\
\text { muscle }\end{array}$ & 8 & $\begin{array}{l}\mathrm{A} \\
\mathrm{B}\end{array}$ & $\begin{aligned} & 0.0257 \\
\pm & 0.0111 \\
& 12.28\end{aligned}$ & $\begin{array}{c}0.0529 \\
\pm 0.0256 \\
26.52\end{array}$ & $\begin{aligned} & 0.0852 \\
\pm & 0.0388 \\
& 42.71\end{aligned}$ & $\begin{aligned} & 0.0357 \\
&+0.0173 \\
& 17.89\end{aligned}$ & $\begin{array}{r}0.1995 \\
\pm 0.0505\end{array}$ \\
\hline $\begin{array}{l}\text { Femoral } \\
\text { muscle }\end{array}$ & 8 & $\begin{array}{l}\mathrm{A} \\
\mathrm{B}\end{array}$ & $\begin{aligned} 0.0093 \\
+0.0059 \\
11.71\end{aligned}$ & $\begin{array}{r}0.0275 \\
\pm 0.0092 \\
34.64\end{array}$ & $\begin{array}{c}0.0259 \\
\pm 0.0144 \\
32.62\end{array}$ & $\begin{aligned} 0.0167 \\
\pm 0.0127 \\
21.03\end{aligned}$ & $\begin{array}{r}0.0794 \\
\pm 0.0245\end{array}$ \\
\hline $\begin{array}{l}\text { Small } \\
\text { intestinal } \\
\text { mucosa }\end{array}$ & 11 & $\begin{array}{l}\mathrm{A} \\
\mathrm{B}\end{array}$ & $\begin{aligned} & 0.0198 \\
&+ 0.0155 \\
& 12.98\end{aligned}$ & $\begin{array}{r}0.0722 \\
\pm 0.0230 \\
50.59\end{array}$ & $\begin{aligned} & 0.0297 \\
& \pm 0.0096 \\
& 19.46\end{aligned}$ & $\begin{array}{r}0.0259 \\
\pm 0.0164 \\
16.97\end{array}$ & $\begin{array}{r}0.1526 \\
+0.0378\end{array}$ \\
\hline
\end{tabular}

The activity is expressed as $-\Delta E(350 \mathrm{m \mu}) / \mathrm{min}$.

TABLE 2

Distribution of Succinic Dehydrogenase Activity in Subcellular Fractions of Mouse Tissues

It shows the degree of contamination of mitocondria.

\begin{tabular}{|c|c|c|c|c|}
\hline Organ & Supernatant & Microsomes & Mitcondria & Nuclei \\
\hline \multirow{5}{*}{ Liver } & \multicolumn{4}{|c|}{ per cent } \\
\hline & 0 & 11.4 & 81.2 & 7.4 \\
\hline & 0 & 0 & 100 & 0 \\
\hline & 0 & 7.4 & 90.9 & 1.7 \\
\hline & 0 & 4.6 & 92.2 & 3.2 \\
\hline Average & 0 & 5.8 & 91.1 & 3.1 \\
\hline \multirow[t]{3}{*}{ Kidney } & 0 & 6.2 & 83.1 & 10.7 \\
\hline & 0 & 8.6 & 80.5 & 10.9 \\
\hline & 0 & 5.3 & 86.2 & 8.5 \\
\hline Average & $\mathbf{0}$ & 6.7 & 83.3 & 10.0 \\
\hline \multirow{3}{*}{$\begin{array}{l}\text { Heart } \\
\text { muscle }\end{array}$} & 0.3 & 65.0 & 28.1 & 6.6 \\
\hline & 0.4 & 67.5 & 23.3 & 9.2 \\
\hline & 0 & 55.1 & 25.4 & 19.5 \\
\hline Average & 0.2 & 62.5 & 25.6 & 11.7 \\
\hline \multirow{3}{*}{$\begin{array}{l}\text { Femoral } \\
\text { muscle }\end{array}$} & 0 & 60.8 & 30.6 & 8.6 \\
\hline & 0 & 62.1 & 29.5 & 8.4 \\
\hline & 0 & 58.6 & 31.4 & 10.0 \\
\hline Average & 0 & 60.5 & 30.5 & 9.0 \\
\hline Small & 7.5 & 50.2 & 42.3 & 0 \\
\hline intestinal & 9.1 & 41.8 & 49.1 & 0 \\
\hline mucosa & 10.7 & 46.7 & 42.6 & 0 \\
\hline Average & 9.1 & 46.2 & 44.7 & $\mathbf{0}$ \\
\hline
\end{tabular}


Even in the heart muscle which contained relatively much enzyme activity, the content was at most $10 \%$. On the contrary, the distribution of the enzyme activity in the microsomal fraction varied considerably according to the tissues. The liver and kidney contained only 6-7 per cent of the activity, whereas heart and femoral muscles contained approximately 60 per cent of the activity in the microsomal fraction, a value twice as much as that in the mitochondrial fraction. The mucosa of the small intestine contained approximately 50 per cent of the enzyme activity, the amount roughly the same as in mitochondrial fraction.

Thus the fractional treatment used in the experiment showed fairly much mitochondrial contamination in the microsomal fraction of the heart, femoral muscles and small intestine mucosa.

\section{Corrected Distribution of NADH-Diaphorase Activity}

Assuming that the succinic dehydrogenase activity found in each subcellular fraction is due to the contamination of mitochondria in each fraction, the NADHdiaphorase activity in each fraction other than in mitochondria shown in Table 1 should be corrected by substracting the activity due to the contamination of mitochondria. The diaphorase activity in the mitochondrial fraction, however, should be corrected by adding the activities detected in other fractions as contamination. The corrected distribution in each fraction of NADH-diaphorase is given in Table 3.

TABLE 3

Distribution of NADH-Diaphorase Activity in Subcellular Frac-

tions of Mouse Tissues

It is corrected for the contamination of succinic dehydrogenose activity.

A, activity; $\mathrm{B}$, percentage activity.

\begin{tabular}{|c|c|c|c|c|c|}
\hline Organ & & Supernatant & Microsomes & Mitochondria & Nuclei \\
\hline Liver & $\begin{array}{l}\mathrm{A} \\
\mathrm{B}\end{array}$ & $\begin{array}{l}0.0677 \\
17.09\end{array}$ & $\begin{array}{l}0.1291 \\
32.59\end{array}$ & $\begin{array}{l}0.1572 \\
39.69\end{array}$ & $\begin{array}{l}0.0421 \\
10.63\end{array}$ \\
\hline Kidney & $\begin{array}{l}\mathrm{A} \\
\mathrm{B}\end{array}$ & $\begin{array}{l}0.0409 \\
14.40\end{array}$ & $\begin{array}{l}0.0774 \\
27.26\end{array}$ & $\begin{array}{c}0.1362 \\
47.96\end{array}$ & 0.0295 \\
\hline $\begin{array}{l}\text { Heart } \\
\text { muscle }\end{array}$ & $\begin{array}{l}\mathrm{A} \\
\mathrm{B}\end{array}$ & $\begin{array}{l}0.0250 \\
\text { Most o }\end{array}$ & activity is & $\begin{array}{c}0.3096 \\
\text { mitochondria }\end{array}$ & 0.0194 \\
\hline $\begin{array}{l}\text { Femoral } \\
\text { muscle }\end{array}$ & $\begin{array}{l}\mathrm{A} \\
\mathrm{B}\end{array}$ & $\begin{array}{l}0.0093 \\
\text { Most o }\end{array}$ & e activity is & $\begin{array}{c}0.0845 \\
\text { mitochondria }\end{array}$ & 0.0091 \\
\hline $\begin{array}{l}\text { Small } \\
\text { intestinal } \\
\text { mucosa }\end{array}$ & $\begin{array}{l}\mathrm{A} \\
\mathrm{B}\end{array}$ & $\begin{array}{l}0.0138 \\
9.04\end{array}$ & $\begin{array}{l}0.0465 \\
30.47\end{array}$ & $\begin{array}{l}0.0664 \\
43.51\end{array}$ & $\begin{array}{l}0.0259 \\
16.98\end{array}$ \\
\hline
\end{tabular}

The activity is expressed as $-\Delta E(350 \mathrm{~m} \mu) / \mathrm{min}$.

The diaphorase activity was poor both in the supernatant and nuclear fraction and much in the mitochondrial fraction. In the microsomal fraction, much activity, approximately 30 per cent of the total, was found in the liver, kidney and small intestinal mucosa. The heart and femoral muscles showed negative value of the enzyme in the microsomal fraction.

\section{Specific Activity of NADH-Diaphorase in Subcellular Fractions}

The specific activity of NADH-diaphorase in each fraction as expressed by the decrease of absorbance at $350 \mathrm{~m} \mu$ per $10 \mathrm{mg}$ of protein is given in Table 4 .

All the tissues tested showed high specific activity both in the mitochondrial 
TABLE 4

Specific Activity of NADH-Diaphorase in Subcellular Fractions of Mouse Tissues

\begin{tabular}{lcrrrr}
\hline \hline \multicolumn{1}{c}{ Organ } & No of cases & Supernatant & Microsomes & Mitochondria & \multicolumn{1}{c}{ Nuclei } \\
\hline Liver & \multirow{2}{*}{10} & 0.834 & 4.907 & 5.531 & 2.055 \\
& & \pm 0.743 & \pm 2.657 & \pm 1.835 & \pm 1.085 \\
Kidney & \multirow{2}{*}{10} & 0.453 & 3.483 & 5.585 & 1.899 \\
& & \pm 0.380 & \pm 1.356 & \pm 2.679 & \pm 0.807 \\
Heart & \multirow{2}{*}{0} & 0.312 & 3.514 & 3.697 & 1.565 \\
muscle & & \pm 0.132 & \pm 0.844 & \pm 1.329 & \pm 0.821 \\
Femoral & \multirow{2}{*}{8} & 0.140 & 2.167 & 2.238 & 0.897 \\
muscle & & \pm 0.071 & \pm 0.614 & \pm 1.697 & \pm 0.648 \\
Small & \multirow{2}{*}{11} & 0.213 & 3.839 & 2.505 & 0.730 \\
intestinal & & \pm 0.146 & \pm 0.865 & \pm 0.716 & \pm 0.422 \\
mucosa & & & & \\
\hline
\end{tabular}

The specific activity is defined as $-\Delta E(350 \mathrm{~m} \mu) /$ protein $10 \mathrm{mg} / \mathrm{min}$.

and microsomal fractions, low in the nuclear fraction, and very low in the supernatant. In the mitochondrial fraction, the specific activity was highest in the liver and kidney, followed by the heart and it was definitely low in femoral muscle and small intestinal mucosa.

The specific activity of the microsomal fraction was also high in the liver, kidney, heart and femoral muscle, but it was lower than that of the mitochondrial fraction, whereas the small intestinal mucosa contained higher specific activity in the microsomal fraction than that in the mitochondrial one.

\section{DISCUSSION}

Subcellular fractionation of the tissue homogenates by centrifugation is usually carried out in a sucrose solution to avoid the agglutination of the particles (12). When the electrolyte solutions are used, the mitochondrial and microsomal fractions will be mixed together. Therefore, in the present experiment, the fractionation was also done in the sucrose solution according to Strittmatter et al. (9). This method is deviced to obtain the particulate fractions of the liver and may have some limitations in applying to the other tissues.

For example, the mitochondria in the small intestinal mucosa are more easily disrupted by homogenization than those of the liver. The muscle fibres must be more strongly homogenized but the mitochondria are then also disrupted.

At any rate, complete fractionation of cellular particles by homogenization and centrifugation is very difficult. Therefore, for investigating the distribution of an enzyme activity in subcellular fractions exactly, one should correct the activity due to contamination of other fractions.

Generally, the nuclei do not contaminate in other fractions and the disrupted mitochondria are easily centrifuged down with the microsomes and the small fragments of microsomes remain in the supernatant. Therefore, the contamination of mitochondria in microsomes should be taken into consideration when the NADHdiaphorase activity is measured in the mitochondrial and microsomal fractions. In 
fact, fairly much amount of mitochondria were shown to be contaminated in the microsomes.

Distribution of the NADH-diaphorase activity corrected for the contamination of mitochondria showed that much activity was associated with both mitochondrial and microsomal fractions in the liver, kidney, and small intestinal mucosa. In the heart and femoral muscle, however, the activity was found concentrated in the mitochondrial fraction, while it was negative in the microsome fraction. It is possibly due to the fact that the contaminated mitochondria in the microsomes had been strongly homogenized, resulting in an apparent rise of the activity by increasing the contact surface of the enzyme with the substrate.

The specific activity of the diaphorase in the mitochondrial fraction was then determined and it was found that the greatest values were obtained in the liver and kidney, followed by the heart muscle, femoral muscle and small intestinal mucosa in the decreasing order. In the latter two tissues, the values were less than half the values of liver and kidney.

The specific activity of the enzyme was also high in the microsomal fraction, but it never surpassed the value of the mitochondrial fraction except for the small intestinal mucosa. In heart and femoral muscles the microsomal fraction showed about the same value as that of the mitochondrial fraction, possibly due to the contamination of the microsomal fraction with the mitochondrial one. On the contrary, in the small intestinal mucosa, the specific activity of the microsomal fraction is markedly greater than that of the mitochondrial one and showed the second-highest activity of all the tissues. Taking into consideration the significant contamination of the microsomal fraction with mitochondria of low specific activity, the specific activity of the microsomal fraction might be much higher.

The physiological role of NADH-diaphorase in microsomes is obscure (13), but it is possibly involved in electron transport considering the property of the enzyme. Strittmatter et al. showed that cytochrome $b_{5}$ served as an electron acceptor of this enzyme in the liver (14-17).

It has been assumed by the authors that the NADH-diaphorase activity in the microsomes plays a role in cell division of the proliferating cells. Comparing the diaphorase activity in the small intestinal mucosa, a tissue showing active cell proliferation with that of the liver and kidney, which are the tissues showing no cell division, it was found that the specific activity of the microsomes of the small intestinal mucosa was relatively higher than that of the mitochondria, although the total activity of the enzyme in the small intestinal mucosa was not so high as that in the liver and kidney. This finding may indicate only a variation of the enzyme activity distribution according to the tissues, but the above findings seem to suggest the involvement of NADH-diaphorase activity of the microsomes in cell division.

\section{SUMMARY}

Subcellular fractions were obtained from the liver, kidney, heart and femoral muscles, and the small intestinal mucosa of mice according to Strittmatter et al. and the distribution of NADH-diaphorase activity and the specific activity of the 
enzyme were examined.

1. The method was suitable for fractionating the liver and kidney tissues, but the microsomal fractions of the heart and femoral muscles and small intestinal mucosa were contaminated with mitochondria.

2. Distribution of the NADH-diaphorase activity in the subcellular fractions was corrected for the contamination of mitochondria. It was found that the liver, kidney, and small intestinal mucosa contained the enzyme activity both in mitochondria and microsomes whereas the heart and femoral muscles contained mainly in mitochondria.

3. In the liver, kidney, heart and femoral muscle, the specific activity of the $\mathrm{NADH}$-diaphorase was higher in mitochondria than in microsomes, whereas it was higher in microsomes than in mitochondria in the small intestinal mucosa.

4. The NADH-diaphorase activity in small intestinal mucosa was as a whole lower than that in liver and kidney, but relatively higher in microsomes than in mitochondria. It was taken as a favorable support of the assumption of the authors that the NADH-diaphorase activity of microsomes was involved in cell proliferation.

\section{REFERENCES}

1. Hogeboom, G. H., Schneider, W. C., and Palade, G. E., J. Biol. Chem. 172, 619 (1948).

2. Siekevitz, P., and Watson, M. L., J. Biophys. Biochem. Cytol. 2, 653 (1956).

3. Long, C., Biochemists' Handbook, Richard Clay and Company, Ltd., p. 820 (1961).

4. Axelrod, A. E., Potter, V.R., and Elvehjem, C. A., J. Biol. Chem. 142, 85 (1942).

5. Burch, H.B., Lowry, O.H., Padilla, A.M., and Combs, A.M., J. Biol.Chem. 223, 29 (1956).

6. Miyaji, K., Baba, K., Ueno, H., Abe, M., Watanabe, M., and Kasho, A., Vitamins 25, 13 (1962).

7. Miyaji, K., and Abe, M., Vitamins 25, 35 (1962).

8. Miyaji, K., Vitamins 27, 163 (1963).

9. Strittmatter, C. F., and Ball, E. G., J. Cell Comp. Physiol. 41, 57 (1954).

10. Lowry, O. H., Rosenbrough, N. J., Farr, A. L., and Randall, R. J., J. Biol. Chem. 193, 265 (1951).

11. Seligman, A. M., and Ruternberg, A., Science 113, 317 (1951).

12. Schneider, W. C., and Hogeboom, G. H., Cancer Res. 11, 1 (1951).

13. Dolin, M. I., The Bacteria, II. p. 441, Academic Press Inc. (1961).

14. Kun, E., Proc. Soc. Exptl. Biol. Med. 77, 441 (1951).

15. Strittmatter, C.F., and Ball, E. G., J. Cell Comp. Physiol. 43, 57 (1954).

16. Strittmatter, P., and Velick, S. F., J. Biol. Chem. 221, 253 (1956).

17. Garfinkel, D., Biochim. Biophys Acta 21, 199 (1954). 